\title{
A STUDY OF INFORMATION SYSTEMS OUTSOURCING INFLUENTIAL FACTORS
}

Claver, Enrique; González, Reyes; Gascó, José and Llopis, Juan.

Alicante University. Facultad de Ciencias Económicas y Empresariales.

Departamento de Organización de Empresas. Carretera San Vicente-Alicante.

03080. Alicante. Spain. Fax and Phone Number: 34-96-5903606. E-mail: mr.gonzalez@ua.es

\begin{abstract}
:
Information Systems Outsourcing is a constantly growing practice in all sorts of organisations. This paper analyses the level of Information Systems outsourcing at Spanish public universities. It also means to determine if factors such as the size, both of universities and of their Information Systems departments, as well as the degree of involvement of Rector's and General Manager's Teams in matters related to Information Technologies can have an influence on the outsourcing level. With this aim, a survey has been made among the Information Systems managers in all the universities under examination.
\end{abstract}

\section{Keywords:}

Information Systems Outsourcing, Public Spanish Universities.

\section{Bibliographic Notes:}

Enrique Claver is a Full Professor in Business Management at the University of Alicante. Head of the Business Management Department at the said University. His current research interests include Strategic Management, Human Resources Management and Information Systems Management.

Reyes González is a Senior Lecturer in Business Management at the abovementioned university. Her Ph.D. dissertation was an empirical research work on the Information Systems Departments in the area of Alicante (east of Spain). Her current research interests are Information Systems Management, E-Business and Outsourcing Processes. 
José Gascó is a Senior Lecturer in Business Management at the University of Alicante. His Ph.D. dissertation was an empirical study of the Human Resources Managers' role in small and medium-sized enterprises (SMEs). His current research interests include Human Resources and Outsourcing Processes.

Juan Llopis is a Senior Lecturer in Business Management and Secretary of the Faculty of Economics and Business Studies at the University of Alicante. His Ph.D. dissertation was an analysis of Corporate Culture. His current research lines include Corporate Culture, Human Resources and Technology Management. 


\section{Introduction}

A growing tendency exists on the part of organisations to examine the different activities of their value chain, in order to externalise those activities that do not form part of their competitive advantage (Ching, Holsapple and Whinston, 1996). Currently, one of the activities which organisations most often choose to externalise is that related to Information Management and, in fact, outsourcing is one of the information services that has grown the most in recent years (Caldwell, 1996; Lacity and Willcocks, 1998; McLellan, Marcolin and Beamish, 1995; Palvia, 1995). What is more, whereas, in the past, outsourcing was restricted to noninformation-intensive factors, in which Information Systems (IS) did not play an essential role in the enterprise's competitiveness, nowadays it is possible to find this type of contract in sectors with a high information content (McLellan, Marcolin and Beamish, 1995).

Taking into account the widespread growth of IS outsourcing, the present paper focuses on the introduction of these services in Spanish public universities, with the intention of determining the degree in which outsourcing is used and whether this use depends on the following factors:

- The size of the university and its IS department (Computers, Data Processing Centre or any other similar name).

- The involvement of the top management in ISs.

As regards the first factor, the argument that production costs are higher in IS departments than for an outside provider could lead us to the conclusion that universities with smaller IS departments will have a stronger tendency to use outsourcing than those having larger IS departments, since the latter will obtain scale economies through the provision of such services. Likewise, we could think that smaller universities have fewer internal resources and prefer to turn their fixed costs into variable ones, that is to say, they would rather keep a minimum IS infrastructure and externalise most of their activities. However, some results suggest that neither the size of the organisation nor that of its IS departments are indicative of a more or less marked tendency to externalisation, or of the success 
or failure to adopt this decision (Grover, Cheon and Teng, 1994: 42; Lacity and Willcocks, 1998: 382-382).

In relation to the second factor, we intend to know the degree of involvement on the part of university's top management (Rector and Vice-Rectors, General Manager and Vice-General Managers) in ISs, considering three aspects: in first place, how they think Information Tecnologies (ITs) contribute to the fulfilment of the university's general objectives; in second place, what their direct relation with ITs is like, in other words, whether or not they use them daily in their work; and finally, seeing what their level of participation is in IS-related decisionmaking. As we have just said, we want to check whether these factors have an influence on IS outsourcing.

The top management's view as regards ITs and their role in IS-linked decision-making, have been repeatedly analysed as factors determining for the good or bad results obtained by organisations' ISs (Brabander and Thiers, 1984; Dos Santos, 1989; Feeny, Edwards and Simpson, 1992; Jarvenpaa and Ives, 1991; Rockart, Earl and Ross, 1996; Ross, Beath and Goodhue, 1996; Schein, 1994; Yap, Soh and Raman, 1992). This is why it becomes important to identify the position adopted by the university top management in front of outsourcing decisions.

Previous studies have reached the conclusion that when top managers collaborated with IS managers in outsourcing decisions, better results were obtained than when both collectives acted separately (Lacity and Willcocks, 1998: 371). It has also been seen that enterprises, whose top managers do not normally use ITs, and in which IS managers have a very distant relationship with the top management, are usually the ones that externalise the most, perhaps because the top management see ISs as a necessary evil, but also as something they do not completely understand, which is why they try to solve these matters in the most economical way and making the least possible efforts, i.e., externalising (Arnett and Jones, 1994: 187). 
Once we have explained the objective of our study we are now going to describe the methodology we have used in this research work, as well as of the results obtained.

\section{Methodology}

In order to deal with the empirical work, we have carried out a survey in the universities under analysis. There is a disadvantage we have to face; namely, the fact that there are hardly any field studies on IS outsourcing in general, since the habitual works about these matters refer to the experiences of specific firms; in other words, they are case studies.

Taking the literature about this topic as our reference, we elaborated the first draft of the questionnaire. We discussed this draft with the head of the University of Alicante's Data Processing Centre [1], who suggested various modifications that helped to enrich the questionnaire. After making the appropriate modifications, a parcel was sent to all 47 Spanish public universities, which contained the final questionnaire, and a presentation letter for the study, in which its objectives were explained; recipients were asked to fill in the questionnaire and guarantees were given that their answers would be anonymous. The parcel also included a stamped addressed envelope, so that the filled-in questionnaire could be returned. The questionnaire recipients were the heads of ISs at the different universities, whose names and addresses were collected after a laborious search through the webpages of each university.

Although we addressed the 47 individuals that form the universe of the survey, we only obtained 35 valid cases. This means we worked with a global error level of \pm 1.2 . These 35 cases account for $74.5 \%$ of the universities.

\section{Results}

The data obtained in the survey have been treated using the SPSS 9.0 software for Windows. 


\section{Profile of Universities and Interviewees}

take in Table I

Organizations interviewed represent the diversity of Spanish university institutions in terms of their age: from those that are over one century old, which account for $17.1 \%$, to the most modern ones created in the 90's (see Table I); the latter are the most numerous, since they account for $31.4 \%$ of the answers obtained, a piece of information that confirms the expansion the Spanish university system has experienced in recent years.

As regards size, most of them (42.9\%) have between 25,000 and 50,000 registered students, while the percentage corresponding to those with less than 25,000 students is lower (37.1\%), and only very few have more than 50,000 students $(17.1 \%)$. Additional data that can be revealing about dimensions have to do with staff. The figures for teaching and research staff in an average university amount to 1,659 people, with a further 701 people dedicated to administration and service tasks. The IS service is included in the second group and counts on 31 workers on average at each university.

The figures above tell us that we find ourselves in front of very complex organisations, considering the number of workers and clients (students) they have.

\section{take in Table II}

As for the IS manager (Table II), to whom the survey is addressed, he has had that job for 5 years on average, and his age ranges between 29 and 57 years old, the average being 41. Most of these responsibility posts are occupied by males, and in terms of the university organisation chart, they are under the authority of the General Manager, of one Vice-Rector, or both.

\section{Outsourced Activities}

take in Table III

The specific activities of IS services are represented on Table III, which shows the percentage of externalisation of those activities at the universities being 
analysed. As can be seen, hardware maintenance, followed by programming, software maintenance, applications analysis and staff and/or user training are the most often externalised activities. However, services such as systems implementation, network services, support to end users, security and system operations are not usually contracted with an external provider.

Anyhow, except for hardware maintenance, universities do not externalise a large proportion of their IS activities. Instead, they opt for a kind of outsourcing that can be called selective. Furthermore, the tasks that are most often contracted with external providers are easily justified; on the one hand, it is customary for hardware and software maintenance to be carried out by providers as an additional updating service. On the other hand, when working peaks arise in these activities, as a result of the development of new systems, it is also common to contract externally the most monotonous part of the development, like, for example, programming. Hence, we can say that Spanish universities do not stand out as organisations externalising a large proportion of their IS activities.

\section{Involvement of the University Top Management in IS Departments}

The interviewees answered a set of questions in which they gave their opinion about the behaviour of the university top management regarding ISs in their university, using the three above-mentioned questions:

- How do they see the role of ISs in the fulfilment of university objectives?

- What is their involvement in IT use?

- What is their role in IS-related decision-making?

$$
\begin{aligned}
& \text { take in Table IV } \\
& \text { take in Table V }
\end{aligned}
$$

The university top management thinks that ISs play an important role in the fulfilment of university objectives; both Rector's and General Manager's Teams agree on that (Table IV). So much so, that nobody questions that ISs are neutral in the achievement of such objectives. As regards the use of ITs (Table V), a large proportion use them directly (as is the case in $45.7 \%$ of Rector's teams and in $40 \%$ 
of General Manager's teams), though a high percentage exists that do not use ISs directly, but who insist on their importance, as well as on the fact that university staff must use them (22.9\% of Rector's teams and $28.6 \%$ of General Manager's teams).

\section{take in Table VI}

Concerning the involvement in IS-related decisions, Table IV shows that a high intervention level exists in these matters, both on the part of Rector's teams and by General Manager's teams. The majority of the answers are either that they are considered the top decision-makers in IT issues (that is the case of $34.3 \%$ of Rector's teams and $17.1 \%$ of the General Manager's teams), or that although they are not the top decision-makers, they also actively participate in these matters (in $28.6 \%$ of Rector's teams and 51.5\% of General Manager's teams). There are fewer cases in which the top management does not intervene a lot in IS-related decisions, but they appoint someone to stand for them in these issues (20\% of Rector's teams and $14.3 \%$ of General Manager's teams) and nobody states that the top management does not participate at all in this decision-making process.

The analysis of Tables IV, V and VI shows that consensus is quite widespread in the actions of Rector's and General Manager's teams. Only in the last table do we find a slight difference regarding the behaviour of both collectives. In order to check whether or not that difference is statistically significant, we have carried out a $T$ test for paired samples. This procedure compares the averages of two variables of a single group, calculates the differences between the values of the two variables in each case and checks if the average is different from 0 . In our case, the aim is knowing whether the behaviour of Rector's teams differs from that of General Manager's teams, at each university. The results of this test appear on Tables VII and VIII, both of which confirm that the behaviour of these two collectives is similar, and that not even their level of intervention in IS decisions (par 3, VIb-VIIb) is different, since T's level of significance is (in all cases) above 0.05 . 


\section{take in Table VIII}

The results obtained for this heading must be analysed taking into account two limitations: firstly, what we present is IS managers' opinion about the top management vision with respect to the new ITs. Therefore, we refer to the opinion of a third party. Furthermore, the no-answer index is quite high, perhaps because these matters were considered very delicate, as they refer to the behaviour of a superior; this is also the case in other research works in which similar topics are dealt with, like that by Arnett and Jones (1994, 183-184).

\section{The incidence of Size on the Outsourcing Level}

take in Table IX

We use Table IX, which shows the correlations (Kendall's Tau-b) between variables measuring size (Ib, Ic, Id y Ie) and externalisation percentages (variables VIIIa to VIIIj) [2], in order to determine whether the size of universities, measured by the number of students, lecturers and researchers as well as the administration and service staff, on the one hand, and the size of the IS department, measured by staff working for this department, on the other, have an impact on the outsourcing level. It is checked that the significant correlations are negative, which is an indication that the larger the size of the university, the less outsourcing is used; this fact is justified if we consider that the largest universities count on a sufficient internal infrastructure that makes it unnecessary for them to choose outside providers.

However, the size of the IS department is only negatively correlated with systems installation and security; this is why we could say that this size, measured by the number of IS staff, does not have a decisive influence on the level of outsourcing.

\section{The University Top Management and the Level of Outsourcing}

take in Table $\mathrm{X}$ 
Finally, we have tried to determine whether the university top management's involvement in ISs can determine the outsourcing level. With this aim, we elaborated Table X, with a structure similar to that of Table IX, which shows significant correlations between variables related to the involvement of Rector's and General Manager's teams in ISs (variables IIIa, IIIb, IVb, Vb, VIb and VIIb) and variables referring to IS externalised activities (variables VIIIa to VIIIj). Also, like in the previous case, significant correlations between both groups of variables are negative. Since high scores (4 or 5) for variables IIIa, IIIb, IVb, Vb, VIb and VIIb imply a lower level of involvement of Rector's and General Manager's teams in ISs, the previous result shows that as the top management's opinion about ISs progressively improves, and as an increase is seen in their IS use level, as well as in their degree of involvement concerning decisions related to these services, IS outsourcing is consequently adopted to a greater extent. This result is completely opposed to that of previous works, like that by Arnett and Jones (1994) and goes clearly against the expectations. Above all, we should note that the most often externalised activity (hardware maintenance, code VIIId) depends on the Rector's team's decisions (VIb); in other words, that activity tends to be more often externalised in universities in which the Rector and Vice-Rector have more decision-making capacity on IS matters. Moreover, programming (VIIIb), which is the second most often externalised activity, depends on the Rector's team's view about ISs (IIIa), as well as on the extent to which both Rector's and General Manager's teams use ISs (IVb and Vb). Therefore, programming activities are more often externalised in those universities in which the top management uses ISs more directly and where the Rector's team thinks that ISs make a large contribution to managerial objectives.

\section{Conclusions}

IS outsourcing is an alternative to the internal management of ITs that is useful for public universities, since it can contribute to IS cost control. However, the level of externalisation at Spanish public universities is not very high; the 
activities that are most often contracted with external providers are hardware and software maintenance along with programming, which can be considered nonspecific activities.

The results analysed confirm that universities under analysis are very complex, considering the number of workers and students these organisations count on.

We can refer to a considerable level of involvement on the part of the university top management in matters related to ISs, since they believe that the role of these systems is basic for the operation of universities; they use ITs directly in their work or, at least, they insist on the fact that university staff should use them and have a significant influence on IS-related decisions made at their respective universities.

The data obtained in this study suggest that the larger the size of the university, the less outsourcing is used, supposedly because there is a sufficient internal infrastructure that makes it unnecessary for them to choose this alternative. However, the size of the IS department itself has no relation whatsoever with the outsourcing level.

The top management's involvement is also related to the outsourcing level; contrary to what was expected, the greater the degree of involvement, the more IS activities are externalised.

We must point out some limitations in this study, since certain results are based on the opinions that IS managers have about Rector's and General Manager's teams at their universities. Therefore, we are explaining the actions of a third party that can be biased, since IS managers could try to give a good image of their superiors. Other limitations, mentioned in the presentation of results too, allow us to offer only signs of behaviours justifying the more or less marked tendency to use IS outsourcing in the organisations being analysed, but prevent us from taking these facts as irrefutable. Anyhow, we hope to have paved the way for a new line of research that can be further developed in later studies. 


\section{Bibliography}

ARNETT, K.P. and JONES, M.C. (1994), "Firms that Choose Outsourcing: A Profile", Information \& Management, Vol. 26 No. 4, pp. 179-188.

BRABANDER, B. and THIERS, G. (1984), "Successful Information System Development in Relation to Situational Factors which Affect Effective Communication Between MIS-users and EDP-specialists", Management Science, Vol. 30 No. 2 , pp. $137-155$.

CALDWELL, B. (1996), "The New Outsourcing Partnership", Information Week, No. 585, pp. 50-64.

CHING, CH.; HOLSAPPLE, C.W. and WHINSTON, A.B. (1996), "Toward IT Support for Coordination in Network Organizations", Information \& Management, Vol. 30 No. 4, pp. 179-199.

DOS SANTOS, B.L. (1989), "Information Systems: Similarities and Differences Across Organizations", OMEGA, Vol. 17 No. 1, pp. 9-20.

FEENY, D. F.; EDWARDS, B. R. and SIMPSON, K. M. (1992), "Understanding the CEO/CIO Relationship", MIS Quarterly, Vol. 16 No. 4, pp. 435-448.

GROVER, V.; CHEON, M.J. and TENG, T.C. (1994), "A Descriptive Study on the Outsourcing of Information Systems Functions", Information \& Management, Vol. 27 No. 1, pp. 33-44.

JARVENPAA, S.L. and IVES, B. (1991), "Executive Involvement and Participation in the Management of Information Technology", MIS Quarterly, Vol. 15 No. 2, pp. 205227.

LACITY, M. and WILLCOCKS, L. (1998), "An Empirical Investigation of Information Technology Sourcing Practices: Lessons from Experience", MIS Quarterly. Vol. 22 No. 3, pp. 363-408.

MCLELLAN, K.; MARCOLIN, B. and BEAMISH, P. (1995), "Financial and Strategic Motivations behind IS Outsourcing". Journal of Information Technology, No. 10, pp. 299-321.

PALVIA, P.C. (1995), "A Dialectic View of Information Systems Outsourcing: Pros and Cons", Information \& Management, Vol. 29 No. 59, pp. 265-275. 
ROCKART, J.F.; EARL, M.J. and ROSS, J.W. (1996), "Eight Imperatives for the New IT Organization", Sloan Management Review, Vol. 38 No. 1, pp. 43-55.

ROSS, J.W.; BEATH, C.M. and GOODHUE, D.L. (1996), "Develop Long-Term Competitiveness through IT Assets", Sloan Management Review, Vol. 38 No. 1, pp. $31-42$.

SCHEIN, E. (1994), "The Role of the CEO in the Management of Change. The Case of Information Technology", in ALLEN, T. J. and SCOTT MORTON, M. S. Information Technology and the Corporation of the 1990's. Research studies, Oxford University Press, New York.

YAP, C.; SOH, C. and RAMAN, K. (1992), "Information Systems Success Factors in Small Business", OMEGA, Vol. 20 No. 5/6, pp. 597-609.

\section{Notes}

[1] This is Mr. Manuel Aparicio, to whom we are very thankful for his collaboration.

[2] Table IX, exactly like Table X, only shows correlations that are significant at a 0.01 or 0.05 level; non-significant correlations do not appear, in order to make result interpretation easier. 
TABLE I: UNIVERSITY PROFILE

\begin{tabular}{|c|c|c|c|c|}
\hline \multicolumn{2}{|c|}{ (Code Ia) Date of Creation } & \multicolumn{3}{|c|}{ (Code Ib) Registered Students } \\
\hline $\begin{array}{ll}\text { More than } & \text { a } \\
\text { century ago } & \end{array}$ & $\begin{array}{r}6 \\
(17.1 \%)\end{array}$ & $0-25,000$ & & $(37.1 \%)$ \\
\hline $1960 / 1979$ & $\begin{array}{r}8 \\
(22.9 \%) \\
\end{array}$ & $25-50,000$ & & $(42.9 \%)$ \\
\hline 1980/1989 & $\begin{array}{r}3 \\
(8.6 \%) \\
\end{array}$ & \begin{tabular}{|ll} 
More & tl \\
$\mathbf{5 0 , 0 0 0}$ & \\
\end{tabular} & ian & $6 \quad(1$ \\
\hline After 1990 & $\begin{array}{r}11 \\
(31.4 \%) \\
\end{array}$ & No answer & & $(2.9 \%)$ \\
\hline No answer & $\begin{array}{r}7 \\
(20.0 \%) \\
\end{array}$ & TOTAL & & $35 \quad(100.0 \%)$ \\
\hline TOTAL & $\begin{array}{r}35 \\
(100.0 \%) \\
\end{array}$ & & & \\
\hline & Minimum & Maximum & Mean & $\begin{array}{c}\text { Std. } \\
\text { Deviation }\end{array}$ \\
\hline $\begin{array}{l}\text { (CodeIc) } \\
(\mathbf{n}=\mathbf{3 3})\end{array}$ & 542 & 3500 & $\begin{array}{r}1659.4 \\
8 \\
\end{array}$ & 883.50 \\
\hline $\begin{array}{lll}(\text { Code } & \text { Id }) & \text { NASS }^{\mathbf{b}} \\
(\mathbf{n}=33) & & \\
\end{array}$ & 200 & 1500 & 701.03 & 379.94 \\
\hline $\begin{array}{lll}(\text { Code } & \text { Ie }) & \text { NISS }^{c} \\
(\mathbf{n}=\mathbf{3 4}) & & \\
\end{array}$ & $\overline{9}$ & 83 & 31.06 & 18.35 \\
\hline
\end{tabular}

${ }^{a}$ Number of Lecturers and Researchers.

${ }^{\mathrm{b}}$ Number of Administrative and Service Staff.

${ }^{c}$ Number of IS Staff.

TABLE II: THE IS MANAGER AT THE UNIVERSITY

\begin{tabular}{|c|c|c|c|c|c|}
\hline & Minimum & \multicolumn{2}{|c|}{ Maximum } & Mean & $\begin{array}{c}\text { Std. } \\
\text { Deviation }\end{array}$ \\
\hline $\begin{array}{l}\begin{array}{l}\text { Length of service } \\
\text { (years) }(n=34)\end{array} \\
(n=3\end{array}$ & 0.5 & \multicolumn{2}{|l|}{13.5} & 5.0 & 3.9 \\
\hline Age $(n=33)$ & 29 & 57 & & 41.8 & 7.4 \\
\hline \multirow[t]{2}{*}{ Sex $(n=31)$} & \multicolumn{2}{|c|}{ Male } & \multicolumn{2}{|c|}{ Female } & No answer \\
\hline & \multicolumn{2}{|c|}{$30(85.7 \%)$} & \multicolumn{2}{|c|}{$1(2.8 \%)$} & $4(11.5 \%)$ \\
\hline \multirow[t]{2}{*}{$\begin{array}{ll}\begin{array}{l}\text { Direct } \\
(n=35)\end{array} & \text { Superior } \\
\end{array}$} & \multicolumn{2}{|c|}{$\begin{array}{l}\text { General } \\
\text { Manager }\end{array}$} & \multicolumn{2}{|c|}{ Vice-Rector } & Both \\
\hline & \multicolumn{2}{|c|}{$10(28.6 \%)$} & & $(42.8 \%)$ & $10(28.6 \%)$ \\
\hline
\end{tabular}

TABLE III: OUTSOURCED IS ACTIVITIES (PERCENTAGES)

Code

VIIId Hardware Maintenance

VIIIb Programming

VIIIe Software Maintenance

VIIIa Applications Analysis

VIIIi Staff and/or User Training

VIIIf Systems Implementation

VIIIg Network Service

VIIIh Support to End Users

\begin{tabular}{|c|c|}
\hline \multicolumn{2}{|c|}{$\begin{array}{c}\text { Externalisation } \\
\text { Percentages }\end{array}$} \\
\hline Mean & $\begin{array}{c}\text { Std. } \\
\text { Deviation }\end{array}$ \\
\hline 70.1 & 33.7 \\
38.1 & 34.8 \\
37.6 & 28.6 \\
28.0 & 32.9 \\
26.6 & 28.1 \\
19.3 & 21.8 \\
15.0 & 20.7 \\
4.3 & 7.7
\end{tabular}


VIIIj Security

VIIIC Systems Operation

4.3

3.7

17.5

10.3

TABLE IV: IS CONTRIBUTION TO THE FULFILMENT OF UNIVERSITY OBJECTIVES

\begin{tabular}{|c|c|c|c|c|c|}
\hline \multirow{6}{*}{$\begin{array}{l}\text { No answer } \\
\text { Very Important } \\
\text { Important } \\
\text { Somewhat } \\
\text { Important } \\
\text { Neutral }\end{array}$} & & \multicolumn{2}{|c|}{$\begin{array}{c}\text { Current } \\
\text { Rector's } \\
\text { Team } \\
\text { Code IIIa }\end{array}$} & \multicolumn{2}{|c|}{$\begin{array}{c}\text { Current } \\
\text { General } \\
\text { Manager's } \\
\text { Team } \\
\text { Code IIIb } \\
\end{array}$} \\
\hline & 0 & & $(5.7 \%)$ & 2 & $(5.7 \%)$ \\
\hline & & & $(51$ & 23 & (65.7\%) \\
\hline & 2 & 15 & $(42.9$ & 8 & $(22.9 \%)$ \\
\hline & & 0 & $(0.0 \%)$ & 2 & $(5.7 \%)$ \\
\hline & & & $(0.0 \%)$ & 0 & \\
\hline
\end{tabular}

TABLE V: USE OF ITS

No answer

They often use these technologies 1 directly They use these technologies symbolically

They insist on the importance of these technologies (teaching and administration staff should use them), 3 but do not use them directly

In general, they promote the use of 4 these technologies

They do not normally use them and do 5 not care about their use either

\begin{tabular}{|rr|rr|}
$\begin{array}{c}\text { Current } \\
\text { Rector's Team } \\
\text { Code IVb }\end{array}$ & \multicolumn{2}{|c|}{$\begin{array}{c}\text { Current } \\
\text { General } \\
\text { Manager's } \\
\text { Team } \\
\text { Code Vb }\end{array}$} \\
\hline 5 & $(14.3 \%)$ & $\begin{array}{c}5 \\
(14.3 \%)\end{array}$ \\
16 & $(45.7 \%)$ & 14 & $(40.0 \%)$ \\
4 & $(11.4 \%)$ & 4 & $(11.4 \%)$ \\
8 & $(22.9 \%)$ & 10 & $(28.6 \%)$ \\
2 & $(5.7 \%)$ & 2 & $(5.7 \%)$ \\
0 & $(0.0 \%)$ & 0 & $(0.0 \%)$ \\
\hline
\end{tabular}

TABLE VI: INTERVENTION IN IS-RELATED DECISIONS

No answer

They are the main decision-makers in 1 these matters

Although they are not the main decisionmakers, they have an active 2 participation

They do not get very involved, but designate somebody to represent them They are quite inactive and do not 4 usually participate

\begin{tabular}{|c|c|}
\hline $\begin{array}{c}\text { Current } \\
\text { Rector's } \\
\text { Team } \\
\text { Code VIb }\end{array}$ & $\begin{array}{c}\text { Current } \\
\text { General } \\
\text { Manager's } \\
\text { Team } \\
\text { Code VIIb }\end{array}$ \\
\hline $\begin{array}{ll}6 & (17.1 \%)\end{array}$ & $6 \quad(17.1 \%)$ \\
\hline 12 (34.3\%) & $6 \quad(17.1 \%)$ \\
\hline $10 \quad(28.6 \%)$ & 18 (51.5\%) \\
\hline $7 \quad(20.0 \%)$ & $5 \quad(14.3 \%)$ \\
\hline $0 \quad(0.0 \%)$ & $0 \quad(0.0 \%)$ \\
\hline
\end{tabular}


TABLE VII: T TEST: STATISTICS OF PAIRED SAMPLES

\begin{tabular}{|c|c|c|c|c|c|c|}
\hline & $\begin{array}{c}\text { M } \\
\text { ean }\end{array}$ & $\mathbf{N}$ & $\begin{array}{c}\text { Std. } \\
\text { Deviati } \\
\text { on }\end{array}$ & $\begin{array}{l}\text { Std. } \\
\text { Error } \\
\text { Mean }\end{array}$ & $\begin{array}{c}\text { Correlati } \\
\text { on }\end{array}$ & Sig. \\
\hline Par 1: & 1.37 & 35 & 0.60 & 0.10 & & \\
\hline $\begin{array}{l}\text { IIIa } \\
\text { IIIb }\end{array}$ & 1.29 & 35 & 0.67 & 0.11 & 0.758 & 0.000 \\
\hline Par 2: & 1.60 & 35 & 1.17 & 0.20 & & \\
\hline $\begin{array}{r}\text { IVb } \\
\text { Vb }\end{array}$ & 1.71 & 35 & 1.20 & 0.20 & 0.838 & 0.000 \\
\hline Par 3: & 1.51 & 35 & 1.01 & 0.17 & & \\
\hline $\begin{array}{r}\text { VIb } \\
\text { VIIb }\end{array}$ & 1.63 & 35 & 0.94 & 0.16 & 0.762 & 0.000 \\
\hline
\end{tabular}

TABLE VIII: T-TEST: PAIRED SAMPLES TEST

\begin{tabular}{|c|c|c|c|c|c|c|c|c|}
\hline & \multicolumn{5}{|c|}{ Paired Differences } & \multirow{3}{*}{$\mathbf{T}$} & \multirow{3}{*}{ df. } & \multirow{3}{*}{$\begin{array}{c}\text { Sig. } \\
(2- \\
\text { tailed) }\end{array}$} \\
\hline & \multirow{2}{*}{ Mean } & \multirow{2}{*}{$\begin{array}{c}\text { Std. } \\
\text { Deviatio } \\
\mathbf{n}\end{array}$} & \multirow[t]{2}{*}{$\begin{array}{l}\text { Std. } \\
\text { Error } \\
\text { Mean }\end{array}$} & \multicolumn{2}{|c|}{$\begin{array}{c}\text { Confidence } \\
\text { Interval of the } \\
\text { Difference }\end{array}$} & & & \\
\hline & & & & Lower & $\begin{array}{c}\text { Uppe } \\
\text { r } \\
\end{array}$ & & & \\
\hline Pair 1: IIIa- & $8.57 \mathrm{E}-$ & 0.45 & $7.53 \mathrm{E}-$ & $-6.73 \mathrm{E}-$ & 0.24 & 1.139 & 34 & 0.263 \\
\hline IIIb & & 0.68 & 02 & 02 & 0.12 & -1.00 & 34 & 0.324 \\
\hline Pair 2: IVb-Vb & -0.11 & 0.68 & 0.11 & -0.35 & 0.12 & & 34 & 0.324 \\
\hline Pair 3: VIb- & -0.11 & & 0.11 & -0.35 & & -1.00 & & \\
\hline VIIb & & & & & & & & \\
\hline
\end{tabular}

TABLE IX: OUTSOURCING AND UNIVERSITY SIZE ${ }^{a}$

\begin{tabular}{|c|c|c|c|c|c|}
\hline $\begin{array}{c}\text { C } \\
\text { ode }\end{array}$ & & Ib & Ic & Id & Ie \\
\hline $\begin{array}{c}\text { VIII } \\
\mathbf{a}\end{array}$ & $\begin{array}{c}\text { Correl. } \\
\text { Coeff. } \\
\text { Significanc } \\
\text { e }\end{array}$ & $\begin{array}{c}-0.350 * \\
0.016\end{array}$ & $\begin{array}{c}-0.280 * \\
0.033\end{array}$ & $\begin{array}{c}-0.325^{*} \\
0.013\end{array}$ & \\
\hline$\underset{\mathbf{b}}{\mathrm{VIII}}$ & $\begin{array}{c}\text { Correl. } \\
\text { Coeff. } \\
\text { Significanc } \\
\text { e }\end{array}$ & $\begin{array}{c}-0.359 * \\
0.013\end{array}$ & & & \\
\hline $\begin{array}{c}\text { VIII } \\
\text { c }\end{array}$ & $\begin{array}{c}\text { Correl. } \\
\text { Coeff. } \\
\text { Significanc } \\
\text { e }\end{array}$ & & & & \\
\hline $\begin{array}{c}\text { VIII } \\
\text { d }\end{array}$ & $\begin{array}{c}\text { Correl. } \\
\text { Coeff. } \\
\text { Significanc } \\
\text { e }\end{array}$ & & & & \\
\hline
\end{tabular}




\begin{tabular}{|c|c|c|c|c|c|}
\hline $\begin{array}{c}\text { VIII } \\
\text { e }\end{array}$ & $\begin{array}{c}\text { Correl. } \\
\text { Coeff. } \\
\text { Significanc } \\
\text { e }\end{array}$ & & & & \\
\hline VIII & Correl & & $-0.328^{*}$ & $-0.339 * *$ & $-0.350 * *$ \\
\hline $\mathbf{f}$ & $\begin{array}{c}\text { Coeff. } \\
\text { Significanc } \\
\mathrm{e}\end{array}$ & & 0.013 & 0.010 & 0.007 \\
\hline $\begin{array}{c}\text { VIII } \\
\text { g }\end{array}$ & $\begin{array}{c}\text { Correl. } \\
\text { Coeff. } \\
\text { Sigificance } \\
\end{array}$ & & & & \\
\hline $\begin{array}{c}\text { VIII } \\
\text { h }\end{array}$ & $\begin{array}{c}\text { Correl. } \\
\text { Coeff } \\
\text { Significanc } \\
\text { e }\end{array}$ & $\begin{array}{c}-0.453^{* *} \\
0.005\end{array}$ & $\begin{array}{c}-0.297 * \\
0.041\end{array}$ & & \\
\hline VIIII & $\begin{array}{c}\text { Correl. } \\
\text { Coeff. } \\
\text { Significanc } \\
\text { e }\end{array}$ & $\begin{array}{c}-0.346^{*} \\
0.019\end{array}$ & & & \\
\hline VIIIJ & $\begin{array}{c}\text { Correl. } \\
\text { Coeff. } \\
\text { Significanc } \\
\text { e } \\
\end{array}$ & $\begin{array}{c}-0.394^{*} \\
0.015\end{array}$ & $\begin{array}{c}-0.399 * * \\
0.006\end{array}$ & $\begin{array}{c}-0.406^{* *} \\
0.005\end{array}$ & $\begin{array}{c}-0.308^{*} \\
0.033\end{array}$ \\
\hline
\end{tabular}

${ }^{\text {a}}$ Significant Correlations (Kendall's Tau-b).

*The correlation is significant at the 0.05 level (2-tailed).

${ }^{* *}$ The correlation is significant at the 0.01 level (2-tailed).

TABLE X: OUTSOURCING AND THE TOP UNIVERSITY MANAGEMENTª

\begin{tabular}{|c|c|c|c|c|c|c|c|}
\hline $\begin{array}{c}\text { C } \\
\text { ode }\end{array}$ & & IIIa & IIIb & IVb & $\mathbf{V b}$ & VIb & VIIb \\
\hline $\begin{array}{c}\text { VIII } \\
\mathbf{a}\end{array}$ & $\begin{array}{c}\text { Correl. } \\
\text { Coeff. } \\
\text { Significanc } \\
\mathrm{e} \\
\end{array}$ & & & & & & \\
\hline $\begin{array}{c}\text { VIII } \\
\text { b }\end{array}$ & $\begin{array}{c}\text { Correl. } \\
\text { Coeff. } \\
\text { Significanc } \\
\text { e } \\
\end{array}$ & $\begin{array}{c}-0.335^{*} \\
0.022\end{array}$ & & $\begin{array}{c}-0.316^{*} \\
0.022\end{array}$ & $\begin{array}{c}-0.379 * * \\
0.006\end{array}$ & & \\
\hline $\begin{array}{c}\text { VIII } \\
\text { C }\end{array}$ & $\begin{array}{c}\text { Correl. } \\
\text { Coeff. } \\
\text { Significanc } \\
\mathrm{e} \\
\end{array}$ & $\begin{array}{c}-0.413^{*} \\
0.011\end{array}$ & $\begin{array}{c}-0.325^{*} \\
0.043\end{array}$ & $\begin{array}{c}-0.482^{* *} \\
0.002\end{array}$ & $\begin{array}{c}-0.490 * * \\
0.001\end{array}$ & $\begin{array}{c}-0.330^{*} \\
0.031\end{array}$ & $\begin{array}{c}-0.319 * \\
0.040\end{array}$ \\
\hline $\begin{array}{c}\text { VIII } \\
\text { d }\end{array}$ & $\begin{array}{c}\text { Correl. } \\
\text { Coeff. } \\
\text { Significanc } \\
\mathrm{e}\end{array}$ & & & & & $\begin{array}{c}-0.474^{* *} \\
0.001\end{array}$ & \\
\hline $\begin{array}{c}\text { VIII } \\
\text { e }\end{array}$ & $\begin{array}{c}\text { Correl. } \\
\text { Coeff. } \\
\text { Significanc } \\
\text { e }\end{array}$ & & & & & & \\
\hline $\begin{array}{c}\text { VIII } \\
\text { f }\end{array}$ & $\begin{array}{c}\text { Correl. } \\
\text { Coeff. } \\
\text { Significanc } \\
\mathrm{e} \\
\end{array}$ & & & & & & \\
\hline $\begin{array}{c}\text { VIII } \\
\text { g } \\
\end{array}$ & $\begin{array}{l}\text { Correl } \\
\text { Coeff. }\end{array}$ & & & & & & \\
\hline
\end{tabular}




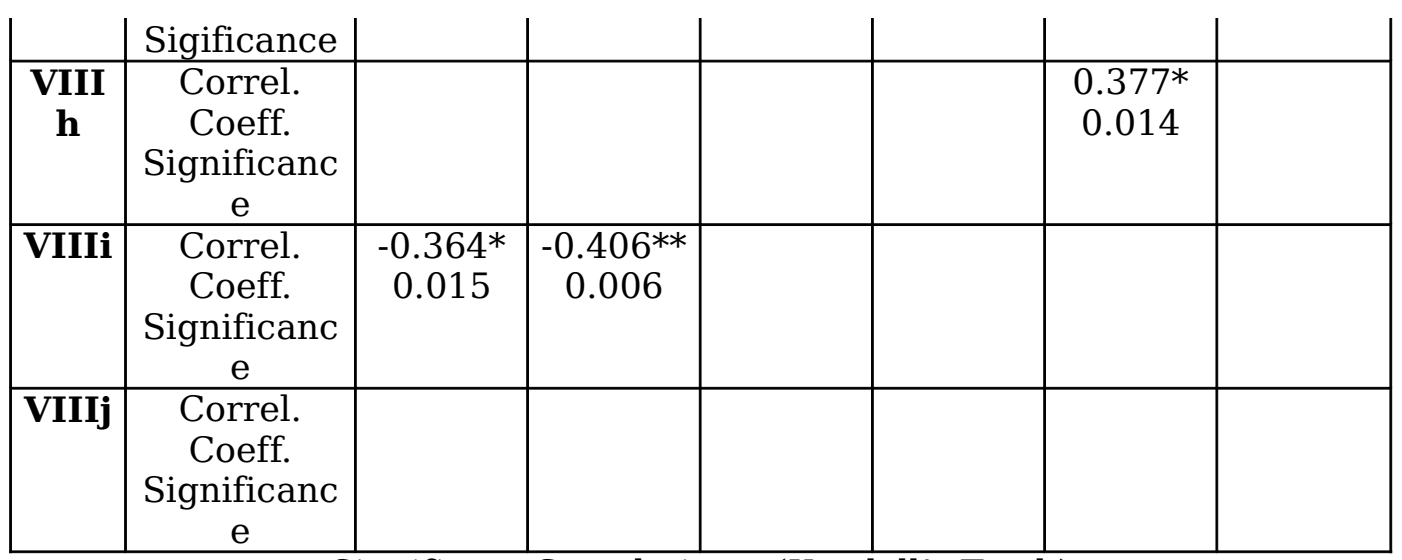

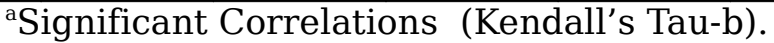

*The correlation is significant at the 0.05 level (2-tailed).

${ }^{* *}$ The correlation is significant at the 0.01 level (2-tailed). 